frequency and distribution of the condition in Great Britain by analysing death certificates in 1967-71. They could not define any regional variations. A major limitation of the survey was the fact that it covered a period when the diagnostic value of the antimitochondrial antibody was not widely established. The authors conceded that their study may not have been representative in that they reported a predominance of patients in social classes I and II, whereas in this study the distribution of the disease more closely paralleled the distribution of social classes in the community. Much more information is needed on the epidemiology of this disorder in this country and elsewhere in the world, both to confirm the regional variation and to test the hypothesis of an environmental agent. Indeed, further studies along these lines might provide clues to the cause of this puzzling disorder.

I thank the medical staff of Sheffield for their help in collecting data; Dr A Milford Ward for the antimitochondrial antibody results; Dr D R Ineson of the Department of Geology, Sheffield University, for trace-metal analysis of reservoir water; and Mr M E Roberts of the Yorkshire Water Authority (Southern Division) for providing information on the Sheffield city water supply, without which this study would have been impossible.

\section{References}

1 Klatskin G, Kantor FS. Mitochondrial antibody in primary biliary cirrhosis and other diseases. Ann Int Med 1972;77:533-41.

2 Sherlock S, Scheuer PJ. The presentation and diagnosis of 100 patients with primary biliary cirrhosis. $N$ Engl f Med 1973;289:674-8.

${ }^{3}$ Cox DR, Hinkley DV. Theoretical statistics. London: Chapman-Hall, 1974:136-7.

4 Logan RAF, Ferguson A, Finlayson NDC, Weir DG. Primary biliary cirrhosis and coeliac disease. Lancet $1978 ; \mathrm{i}: 230-3$.

5 Fagan E, Cox S, Williams R. Primary biliary cirrhosis in mother and daughter. Br Med f 1977; ii:1195.

6 Tong MJ, Nies KM, Reynolds TB, Quismorio FP. Immunological studies in familial primary biliary cirrhosis. Gastroenterology 1976;71:305-7.

${ }^{7}$ Douglas JG, Finlayson NDC. Are increased individual susceptibility and environmental factors both necessary for the development of primary biliary cirrhosis ? $\mathrm{Br}$ Med $\mathcal{F}$ 1979;ii:419-20.

8 Epstein O, Arborgh B, Wroblewski R, Segiv M, Scheuer PJ, Sherlock S. Is copper hepatotoxic in primary biliary cirrhosis? Gut 1979;10:A954.

${ }^{9}$ Fleming CR, Dickson ER, Bagenstoss AH, McCall JT. Copper and primary biliary cirrhosis. Gastroenterology 1974;67:1182-7.

10 Platts MM, Goode GC, Hislop JS. Composition of the domestic water supply and the incidence of fractures and encephalopathy in patients on home dialysis. $\operatorname{Sr} \mathrm{Med} \mathcal{F} 1977$;ii :657-60.

11 Hamlyn AN, Sherlock S. The epidemiology of primary biliary cirrhosis a survey of mortality in England and Wales. Gut 1976;15:473-9.

(Accepted 28 fuly 1980)

\title{
Cimetidine and ranitidine: comparison of effects on hepatic drug metabolism
}

\author{
D A HENRY, I A MACDONALD, G KITCHINGMAN, G D BELL, M J S LANGMAN
}

\section{Summary and conclusions}

Paired studies of hepatic microsomal function were conducted in eight subjects during treatment with two histamine $\mathrm{H}_{2}$ antagonists, cimetidine and ranitidine. Cimetidine but not ranitidine inhibited the metabolism of antipyrine (phenazone) and demethylation of aminopyrine (aminophenazone) as measured by breath ${ }^{14} \mathrm{CO}_{2}$ production after intravenous injection of ${ }^{14} \mathrm{C}$-aminopyrine.

These results suggest that the metabolic inhibitory actions on the liver may be separated from $\mathrm{H}_{2}$ antagonist effects, and that ranitidine has an advantage over cimetidine by not inhibiting microsomal drug oxidative function.

\section{Introduction}

When drugs such as warfarin, antipyrine (phenazone), and diazepam are taken with cimetidine their metabolism is retarded. $^{2}$ This interaction has been attributed to the

\footnotetext{
University Department of Therapeutics, City Hospital, Nottingham NG5 1PB

D A HENRY, MRCP, lecturer

G KITCHINGMAN, MIST, laboratory scientific officer

G D BELL, MD, MRCP, senior lecturer

M J S LANGMAN, MD, FRCP, professor

University Department of Physiology and Pharmacology, Queen's Medical Centre, Nottingham NG7 2UH

I A MACDONALD, PHD, lecturer
}

imidazole ring structure of cimetidine. ${ }^{1}$ Many imidazole compounds inhibit hepaticmono-oxyxgenase function, ${ }^{3}$ and in the case of cimetidine this effect may be mediated in part through direct binding to microsomal cytochrome P450. ${ }^{4}$ Ranitidine is a new potent $\mathrm{H}_{2}$-receptor antagonist. ${ }^{5}$ The central imidazole group has been replaced by a furan ring and the side chain has been modified. We have compared the effects of therapeutic doses of cimetidine and ranitidine on hepatic microsomal function.

\section{Subjects and methods}

Eight subjects (six healthy volunteers and two patients with duodenitis) were studied after the nature and purpose of the investigation had been explained and after approval had been obtained from the hospital ethical committee. Antipyrine clearance was measured in all eight subjects and ${ }^{14} \mathrm{C}$-aminopyrine $\left({ }^{14} \mathrm{C}\right.$-aminophenazone) breath analysis conducted in six subjects before and during treatment with cimetidine $1 \mathrm{~g}$ daily and ranitidine $200 \mathrm{mg}$ daily. The studies were performed in a cross-over fashion. Five subjects took cimetidine followed by ranitidine, the remainder ranitidine followed by cimetidine. Cimetidine was given for one to six weeks, and ranitidine for one week only (see table).

Antipyrine $(15 \mathrm{mg} / \mathrm{kg})$ was taken by mouth during fasting and saliva collected at intervals from three to 24 hours afterwards. Antipyrine concentrations were measured spectrophotometrically ${ }^{6}$ and the half life and metabolic clearance rates calculated from the semilogarithmic plot of salivary concentration against time.

\section{${ }^{14}$ C-AMINOPYRINE BREATH ANALYSIS}

The procedure was as described. 7 All studies were performed on fasting subjects. After intravenous administration of $2 \mu \mathrm{Ci}{ }^{14} \mathrm{C}$ aminopyrine, $2 \mathrm{mmol}^{*}$ exhaled carbon dioxide was trapped in a 
Half lives of phenazone and breath ${ }^{14} \mathrm{CO}_{2}$ from ${ }^{14} \mathrm{C}$-aminopyrine before and during treatment with cimetidine $1 \mathrm{~g}$ and ranitidine $200 \mathrm{mg}$ daily

\begin{tabular}{|c|c|c|c|c|c|c|c|c|}
\hline \multirow[b]{3}{*}{ Subject } & \multirow{2}{*}{\multicolumn{2}{|c|}{ Before treatment }} & \multicolumn{6}{|c|}{ During treatment } \\
\hline & & & \multicolumn{3}{|c|}{ Cimetidine } & \multicolumn{3}{|c|}{ Ranitidine } \\
\hline & $\underset{t \frac{1}{2}(h)}{\text { Antipyrine }}$ & $\underset{\mathbf{t}_{2}^{1}(h)}{\text { Breath }}$ & $\begin{array}{c}\text { Duration of } \\
\text { treatment } \\
\text { (weeks) }\end{array}$ & $\underset{t \frac{1}{2}(h)}{\text { Antipyrine }}$ & $\begin{array}{c}\text { Breath }{ }^{14} \mathrm{CO}_{2} \\
\mathrm{t}^{1}(\mathrm{~h})\end{array}$ & $\begin{array}{c}\text { Duration of } \\
\text { treatment } \\
\text { (weeks) }\end{array}$ & $\underset{t: 2(t)}{\text { Antipyrine }}$ & $\begin{array}{c}\text { Breath }{ }^{14} \mathrm{CO}_{2} \\
\mathrm{t}: \frac{1}{2}(\mathrm{~h})\end{array}$ \\
\hline $\begin{array}{l}1 \\
2 \\
3 \\
4 \\
5 \\
6 \\
7 \\
7 \\
8\end{array}$ & $\begin{array}{c}10 \cdot 1 \\
9 \cdot 7 \\
13.8 \\
11 \cdot 7 \\
\frac{12}{12} \cdot 3 \\
14.5 \\
12 \cdot 2\end{array}$ & $\begin{array}{l}2 \cdot 7 \\
2 \cdot 5 \\
2 \cdot 8 \\
2 \cdot 9 \\
2 \cdot 0 \\
3 \cdot 2 \\
=\end{array}$ & $\begin{array}{l}1 \\
4 \\
1 \\
1 \\
6 \\
4 \\
1 \\
1\end{array}$ & $\begin{array}{l}17 \cdot 3 \\
14 \cdot 2 \\
14 \cdot 8 \\
13 \cdot 0 \\
13 \cdot 7 \\
21 \cdot 3 \\
13 \cdot 7 \\
16 \cdot 3\end{array}$ & $\begin{array}{l}4 \cdot 0 \\
3 \cdot 9 \\
3 \cdot 2 \\
3 \cdot 5 \\
3 \cdot 3 \\
3 \cdot 7 \\
=\end{array}$ & $\begin{array}{l}1 \\
1 \\
1 \\
1 \\
1 \\
1 \\
1 \\
1\end{array}$ & $\begin{array}{r}9 \cdot 5 \\
12.7 \\
15 \cdot 0 \\
11 \cdot 0 \\
8 \cdot 8 \\
\frac{14}{14} \cdot 0 \\
10 \cdot 2\end{array}$ & $\begin{array}{l}3 \cdot 1 \\
2 \cdot 6 \\
4 \cdot 4 \\
2 \cdot 6 \\
1 \cdot 9 \\
= \\
=\end{array}$ \\
\hline
\end{tabular}

phial of hyamine hydroxide at hourly intervals up to 12 hours. After adding scintillant the ${ }^{14} \mathrm{C}$ produced by demethylation of ${ }^{14} \mathrm{C}$-aminopyrine was measured in a liquid scintillation counter. The degree of quenching of individual phials was estimated by external standardisation. The half life of breath ${ }^{14} \mathrm{CO}_{2}$ was calculated from a semilogarithmic plot of the breath specific activities beyond two hours. ${ }^{8}$

To measure accurately the proportion of the dose of ${ }^{14} \mathrm{C}$-aminopyrine demethylated in unit time the method was modified to permit semi-continuous collection and simultaneous measurement of drugderived ${ }^{14} \mathrm{CO}_{2}$ and endogenous, unlabelled carbon dioxide. In four subjects all expired gases were collected for five out of every 10 minutes for one hour after administration of ${ }^{14} \mathrm{C}$-aminopyrine. The procedure was repeated during treatment with cimetidine and ranitidine. Subjects wore a nose clip and breathed through a valved mouthpiece into Douglas bags. The composition of dry gas was determined with an infrared carbon dioxide analyser and a paramagnetic oxygen analyser. The gas analysers were calibrated with standard gases every 20 minutes throughout each experiment. The ${ }^{14} \mathrm{CO}_{2}$ content of the expired air was determined by trapping $20 \mathrm{mmol}^{*}$ carbon dioxide from each Douglas bag in hyamine hydroxide. A diaphragm pump drove the bag contents through the hyamine and returned the carbon-dioxide-free gas to the bag. The variability of trapping was determined by reanalysis of each bag and found to be less than $1.3 \%$. The volume of gas remaining in each bag was determined with a dry gas meter, and after correcting the total gas volume (including the volume of the samples and trapped carbon dioxide) to standard temperature and pressure, dry, the carbon dioxide output, oxygen uptake, and respiratory exchange ratios were calculated. The ${ }^{14} \mathrm{C}$ content of the trapped carbon dioxide was determined by counting $2 \mathrm{ml}$ aliquots of the saturated hyamine in triplicate as described above. The percentage of the administered dose demethylated in each minute was calculated from the product of carbon dioxide production rate and carbon dioxide specific activity.

Statistical analyses were by paired $t$ test.

\section{Results}

Cimetidine prolonged the half life of antipyrine from a mean of $12.0 \pm \mathrm{SD} 1.8 \mathrm{~h}$ to $15.8 \pm 2.8 \mathrm{~h}(\mathrm{n}=7, \mathrm{p}<0.05$; table $)$. There was no alteration in the calculated volumes of distribution, and antipyrine clearance rates were reduced from $45.3+\mathrm{SD} 12.4 \mathrm{ml} / \mathrm{min}$ to $33.2+$ $11.3 \mathrm{ml} / \mathrm{min}(\mathrm{n}=7, \mathrm{p}<0.02)$. After treatment with ranitidine the mean half life was $12 \cdot 1 \pm 2 \cdot 2 \mathrm{~h}$ and the clearance rate $49 \cdot 1 \pm 5 \cdot 2 \mathrm{ml} / \mathrm{min}$. These were not significantly different from the control values.

The half lives of breath ${ }^{14} \mathrm{CO}_{2}$ were increased from a mean of $2 \cdot 7 \pm \operatorname{SD} 0.4 \mathrm{~h}$ to $3.6 \pm 0.3 \mathrm{~h}$ by cimetidine $(\mathrm{n}=6, \mathrm{p}<0.005)$ but were unchanged by ranitidine $(2 \cdot 9 \pm 0.9 \mathrm{~h})$. The figure shows the profile of ${ }^{14} \mathrm{CO}_{2}$ elimination during semi-continuous analysis and the effects of treatment with cimetidine and ranitidine. After intravenous administration of ${ }^{14} \mathrm{C}$-aminopyrine, breath ${ }^{14} \mathrm{CO}_{2}$ concentrations rose rapidly and then remained constant for one to two hours before declining exponentially. At all times other than during the first 10 minutes of the study cimetidine produced a highly significant reduction in the output of ${ }^{14} \mathrm{CO}_{2}$. No such effect was seen with ranitidine. The total extent of demethylation of ${ }^{14} \mathrm{C}$-aminopyrine in the first hour after administration was reduced from a mean of $4.9 \pm$ SD $0.6 \%$ to $3.1 \pm 0.6 \%$ of the administered dose $(n=4, p<0.02)$. It was unchanged by ranitidine $(4 \cdot 7 \pm 0.9 \%)$. Endogenous carbon dioxide production in these four subjects ranged from $6 \cdot 2$ to 9.6 (mean $7 \cdot 9 \pm \mathrm{SD} 1 \cdot 1) \mathrm{mmol}^{*} / \mathrm{h} / \mathrm{kg}$ body weight and was unaffected by

*Conversion factor: $1 \mathrm{mmol} \mathrm{CO}_{2} \approx 22.3 \mathrm{ml}$ at STPD.

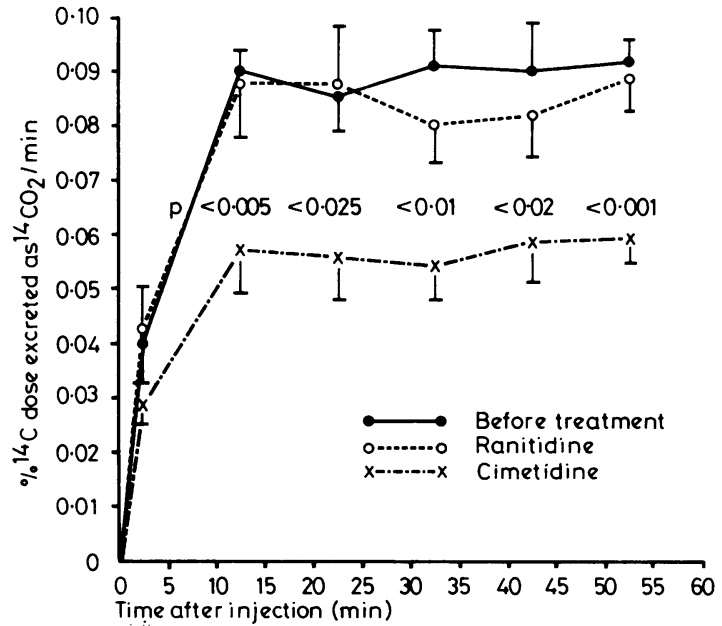

Profile of ${ }^{14} \mathrm{CO}_{2}$ excretion after intravenous ${ }^{14} \mathrm{C}$-aminopyrine administration in four subjects before and during treatment with cimetidine and ranitidine. Results given as means ISEM; significance values are of differences between values before treatment and during treatment with cimetidine (paired $t$ test).

$\mathrm{H}_{2}$-receptor blockade. In all cases calculated values for respiratory exchange ratios and oxygen consumption were within the physiological range for fasting adults at rest.

\section{Discussion}

Antipyrine clearance and ${ }^{14} \mathrm{CO}_{2}$ breath analysis after ${ }^{14} \mathrm{C}$ aminopyrine administration are reliable tests of hepatic microsomal drug oxidative function. ${ }^{8}{ }^{9}$ The modified ${ }^{14} \mathrm{C}$-aminopyrine breath test described here permits simultaneous measurement of ${ }^{14} \mathrm{CO}_{2}$ and endogenous, unlabelled carbon dioxide, and thus the precise extent of demethylation of aminopyrine may be found.

Our results confirm that the microsomal enzyme inhibition produced by cimetidine is a consequence of the chemical structure of the drug and is unrelated to $\mathrm{H}_{2}$-receptor blockade. ${ }^{1}$ Ranitidine in doses that we have shown to be equipotent for duodenal ulcer healing ${ }^{10}$ and others have found to give equipotent secretory inhibition ${ }^{5}$ produced no changes in the indices of drug metabolism measured in this study. The effect of cimetidine on antipyrine metabolism was highly variable in our subjects, but tho mean reduction in clearance was almost identical with reported figures. ${ }^{12}$ The inhibition of aminopyrine metabolism was of a similar magnitude despite in-vitro studies showing that imidazole compounds interfere with $n$-demethylation less than other microsomal oxidative functions. ${ }^{3}$ That drug interactions of this type are clinically important was shown by Serlin et al for warfarin, ${ }^{1}$ and Klotz et al for diazepam. ${ }^{2}$ Peptic ulcer is increasingly a disease of the elderly, who commonly receive several drugs simultaneously, many of which are extensively metabolised in the liver. These patients are at particular risk of side effects resulting from coadministration of inhibitors of microsomal drug 
oxidative function. Our results suggest that ranitidine has an advantage over cimetidine in being free of this effect.

We thank Mrs E E Mullins, Mrs D Sharrock, and the other members of staff in the cardiorespiratory laboratory, City Hospital, Nottingham, for their help.

\section{References}

${ }^{1}$ Serlin MJ, Sibeon RG, Mossman S, et al. Cimetidine: interactions with oral anticoagulants in man. Lancet 1979;ii:317-9.

2 Klotz U, Reimann I. Delayed clearance of diazepam due to cimetidine. $N$ Engl f Med 1980;302:1012-4.

3 Wilkinson CF, Hetnarski K, Hicks LJ. Substituted imidazoles as inhibitors of microsomal oxidation and insecticide synergists. Pesticide Biochem Physiol 1973;4:299-312.
${ }^{4}$ Reudić S, Sunjić V, Toso R, et al. Interaction of cimetidine with liver microsomes. Xenobiotica 1979;9:555-64.

${ }^{5}$ Peden NR, Saunders JHB, Wormsley K. Inhibition of pentagastrin stimulated and nocturnal gastric secretion by ranitidine. Lancet $1979 ; \mathrm{i}$ : 690-2.

${ }^{6}$ Brodie B, Axelrod J, Soberman R, Levy B. The estimation of antipyrine in biological materials. f Biol Chem 1949;179:25-9.

${ }^{7}$ Henry D, Sharpe G, Chaplain S, et al. The ${ }^{14} \mathrm{C}$ aminopyrine breath test. A comparison of different forms of analysis. Br $\mathcal{F}$ Clin Pharmacol 1979 8:539-45.

${ }^{8}$ Platzer R, Galeazzi R, Karlaganis G, Bircher J. Rate of drug metabolism in man measured by ${ }^{14} \mathrm{CO}_{2}$ breath analysis. Eur $\mathcal{F}$ Clin Pharmacol 1978;14: 293-9.

${ }^{9}$ Stevenson IH. Factors influencing antipyrine elimination. $\mathrm{Br} f \mathrm{Clin}$ Pharmacol 1977;4:261-5.

${ }^{10}$ Langman MJS, Henry DA, Bell GD, et al. Cimetidine and ranitidine in duodenal ulcer. $B r M e d \mathcal{F} 1980 ; 281: 473-4$.

(Accepted 25 Fuly 1980)

\title{
Radioimmunoassay of serum creatine kinase BB as index of brain damage after head injury
}

\author{
J P PHILLIPS, HILARY M JONES, ROWENA HITCHCOCK, N ADAMS, R J THOMPSON
}

\section{Summary and conclusions}

Brain-type creatine kinase isoenzyme (CK-BB) was measured by radioimmunoassay in the serum of 54 patients with head injuries. CK-BB was not detectable in 476 out of 1006 controls, the remaining 530 normal samples containing a mean of $1.5 \pm \mathrm{SDO} \cdot 75 \mu \mathrm{g} / \mathrm{l}$. The mean CK-BB concentrations in patients with mild, moderate, and fatal head injuries were all significantly higher than the control value ( $p<0.01$ in each instance). Patients with serious head injury had serum concentrations many times the normal value, in two cases within 30 minutes after impact. Fatally injured patients continued to have high serum concentrations several days after injury. In less serious cases values approached normal within two or three days. Every patient with evidence of cerebral laceration, bruising, or swelling had a serum CK-BB concentration above normal. Raised concentrations were found in 14 out of 22 patients with concussion only.

The serum CK-BB concentration appears to be a sensitive index of brain damage and may prove useful in the management and follow-up of head-injured patients.

\section{Introduction}

A biochemical index of the extent of brain damage might be of great value in assessing and managing patients with head injury. Several proteins have been measured in serum and cerebrospinal fluid after trauma, including lactate dehydrogenase

\footnotetext{
University Department of Neurosurgery and Clinical Biochemistry, School of Clinical Medicine, Addenbrooke's Hospital, Cambridge CB2 2QR

J P PHILLIPS, MD, FRCs, clinical lecturer in neurosurgery HILARY M JONES, BSC, research assistant

ROWENA HITCHCOCK, BA, medical student

$\mathrm{N}$ ADAMS, $\mathrm{MB}, \mathrm{BCH}$, senior house officer

R J THOMPSON, MB, PHD, lecturer and honorary consultant
}

isoenzymes, ${ }^{1-6}$ creatine kinase isoenzymes, ${ }^{78}$ and myelin basic protein. ${ }^{910}$ Though such studies usually show a correlation between the serum concentration of the marker protein and the extent of the cerebral lesion, the methods may not be sensitive enough to monitor minor degrees of brain damage, and no one marker protein has become established in patient care. Brain-type creatine kinase isoenzyme (CK-BB) has been measured in head injuries by fluorescence ${ }^{7}$ and by spectrophotometry. ${ }^{8}$ Bell et al ${ }^{11}$ measured CK-BB by radioimmunoassay in serum and cerebrospinal fluid from patients with neurological disorders and found significantly increased mean values in those with acute cerebrovascular accidents, patients with prolonged alterations of consciousness, and in a single patient with head injury. We developed a similar radioimmunoassay for $\mathrm{CK}-\mathrm{BB}$ and found significantly raised mean serum concentrations in patients with dementia and also isolated raised values in patients with epilepsy, cervical myelopathy, and cerebellar degeneration. ${ }^{12}$ Apart from neurological disorders radioimmunoassay has shown raised serum $\mathrm{CK}-\mathrm{BB}$ concentrations in malignant diseases. ${ }^{13}$

Radioimmunoassays for creatine kinase isoenzyme estimation are reportedly about 1000 times more sensitive than conventional spectrophotometry ${ }^{14}$ and furthermore recognise enzymically inactive but immunologically reactive protein. We have therefore used radioimmunoassay to measure $\mathrm{CK}-\mathrm{BB}$ in the serum of 54 patients with head injury to see whether the concentration is a sensitive index of brain damage.

\section{Patients and methods}

The 54 patients were divided into three groups according to the early outcome (death or discharge).

Group 1 comprised 25 patients with mild head injury resulting in loss of consciousness for under 10 minutes. Three patients had transient neurological signs detectable after they regained consciousness, but the remaining 22 were concussed only. All patients fully recovered and showed no residual disability on discharge.

Group 2 comprised 19 patients with serious head injury resulting in some residual deficit on discharge.

Group 3 comprised 10 patients with isolated severe head injury resulting in death. 